\title{
Sistem Homeschooling Terhadap Efektivitas Pembelajaran
}

\author{
Meilani Fatzuarni \\ E-mail: meilanifatzuarni@gmail.com \\ Program Studi Pendidikan Bahasa dan Sastra Indonesia, Universitas Riau
}

\section{Pengantar}

Pendidikan merupakan unsur yang paling penting bagi kemajuan peradaban bangsa. Era Industri dan globalisasi membawa dampak terhadap proses pendidikan terutama di Indonesia. Di satu sisi, globalisasi memberi dampak positif, namun di sisi lain, dominasi teknologi membawa dampak negatif, yakni menimbulkan dehumanisasi dalam bentuk mentalitas yang terlalu mengagungkan teknologi di atas segalanya. Realitasnya, pendidikan di era globalisasi saat ini mengalami krisis nilai. Pendidikan hanya menghasilkan output-output yang pintar secara kognitif, menguasai teori dan teknologi tetapi kering dari nilai-nilai kemanusiaan dan sosial (dehumanisasi).

Banyaknya orangtua yang tidak puas dengan sekolah formal mendorong orangtua mendidik anaknya di rumah. Kerapkali sekolah formal berorientasi pada nilai rapor (kepentingan sekolah), bukannya menegdepankan keterampilan hidup dan bersosial yaitu nilai iman dan moral. Di sekolah, banyak murid mengejar nilai rapor dengan mencontek atau membeli ijazah palsu. Selain itu perhatian secara personal pada anak, kurang diperhatikan. Ditambah lagi, identitas anak distigmatisasi dan ditentukan oleh teman-temannya yang lebih pandai, lebih unggul atau lebih cerdas. Keadaan yang demikian menambah lingkungan di sekolah menjadi tidak menyenangkan.

Ketidakpuasan tersebut mengakibatkan orangtua memilih mendidik anaknya di rumah, dengan resiko menyediakan banyak waktu dan tenaga. Homeschooling menjadi tempat harapan orangtua untuk meningktakan mutu pendidikan anak, mengembangkan nilai-nilai iman dan moral serta mendapatkan suasan belajar yang menyenangkan.

Homeschooling merupakan bahasa inggris yang terdiri dari kata home dan school. Menurut kamus bahasa Inggris homeschooling merupakan bentuk kata kerja, homeschooling is to instruct (a pupil, for example) in an educational program outside of established schools, especially in the home. Homeschooling berarti membimbing seperti seorang murid dalam program pendidikan luar sekolah umum, khususnya dilaksanakan di rumah. 
Homeschooling adalah menyekolahkan anak di rumah yang dipertanggungjawabkan oleh keluarga atau orangtua dan menentukan sendiri metode pengajaran yang tepat sesuai kemampuan, minat, bakat, potensi dan gaya belajar peserta didik.

\section{Tindakan Yang Dilakukan}

a. Menciptakan suasana kondusif demi mengembangkan bakat dan potensi peserta didik

Sistem pendidikan berbasis rumah ini bukanlah hal baru. Bahkan, sejak pandemi COVID-19, sekolah pun menjadi "semi" homeschooling dengan adanya Belajar Di Rumah (BDR). Guru memberikan kisi-kisi materi dan pembelajaran online, kemudian anak bersama orang tua mengeksekusi pelajaran di rumah. Di luar musim pandemi pun, banyak orang tua telah menjalankan sistem ini untuk pendidikan anak. Tujuan akhir yang ingin dicapai dengan sistem pendidikan berbasis rumah ini bervariasi. Namun, secara singkat dapat dirangkum menjadi beberapa poin penting. Beberapa poin ini antara lain, motivasi anak dalam belajar, fokus pada tujuan yang ingin dicapai, disesuaikan dengan kondisi anak, kemandirian dan manajemen diri pada anak, dan kerja sama orang tua dan peserta didik.

Di masa covid-19, aktivitas belajar dilakukan secara daring sehingga menuntut mahasiswa belajar secara mandiri dan melatih skilnya agar dapat mencapai tujuan pembelajaran. Dalam situasi ini, Peserta didik menjadi pengontrol utama dalam aktivitas belajarnya. Maka peserta didik perlu memilih dan memiliki metode belajar yang tepat agar kualitas belajarnya stabil.

Dalam segi akademis, minat dan bakat, Homeschooling lebih efektif dibandingkan sekolah formal. Karena dengan Homeschooling, peserta didik lebih terarah pada minat bakatnya. Dalam Homeschooling peserta didik akan belajar sesuai dengan gaya belajarnya masing-masing. Dengan menciptakan suasana belajar yang sesuai, peserta didik akan merasa nyaman, proses belajar akan menyenangkan sehingga peserta didik akan berkembang secara optimal.

Para orang tua sadar akan pentingnya pengembangan talenta dan minat anak,maka orangtua menyediakan sarana yang memadai di rumah menggunakan tujuan agar anak sibuk belajar di rumah dan terhindar dari pergaulan yg kurang positif. 
b. Mengembangkan pengetahuan dan keterampilan fungsional serta perkembangan sikap profesional

Homeschooling sebagai pendidikan alternatif yang diselenggarakan di rumah bertempu pada susasan belajar keluarga dengan menempatkan anak sebagai subjek. Sebai akibatnya anak merasa nyaman untuk belajar apapun sinkron dengan apa yang diinginkan anak, kapan saja karena pelaksanaan homeschooling tidak terbatas ruang serta waktu. Pembelajaran Homeschooling bisa dimana saja seperti taman bermain serta kawasan lainnya yang dijadikan sebagai alat tempat serta mendukung pengetahuan anak secara konkrit.

Homeschooling tidak akan menjadikan terhambatnya inovatif, kreatif serta keterampilan peserta didik bahkan homeschooling akan lebih mengembangkan sikap inovatif, kreatif dan berketrampilan pada peserta didik karena homeschooling akan fokus terhadap satu peserta didik juga akan diawasi oleh orangtua atau keluaga.

Inovasi pendidikan adalah suatu perubahan yang baru dan kualitatif berbeda dari keadaan yang ada sebelumnya dengan sengaja diusahakan untuk meningkatkan kemampuan guna mencapai tujuan tertentu secara maksimal dalam pendidikan. Tegasnya inovasi pendidikan adalah pembaruan dalam bidang pendidikan atau inovasi yang dilakukan untuk memecahkan masalah-masalah pendidikan.

\section{Sarana Pendukung}

a. Buku Pedoman

b. Media Pembelajaran

c. Ruang Belajar

d. Pakar-pakar bidang pendidikan

Pembelajaran homeschooling harus didukung oleh sara pendukung yan efektif seperti buku pedoman, media pembelajaran, raung belajar dan pakar-pakar bidang pendidikan. Agar terciptanya pembelajaran yang efektif dan efesian karen telah didukung oleh sarana dan prasana sehingga belajar pun semakin mudah dan terjamin. 


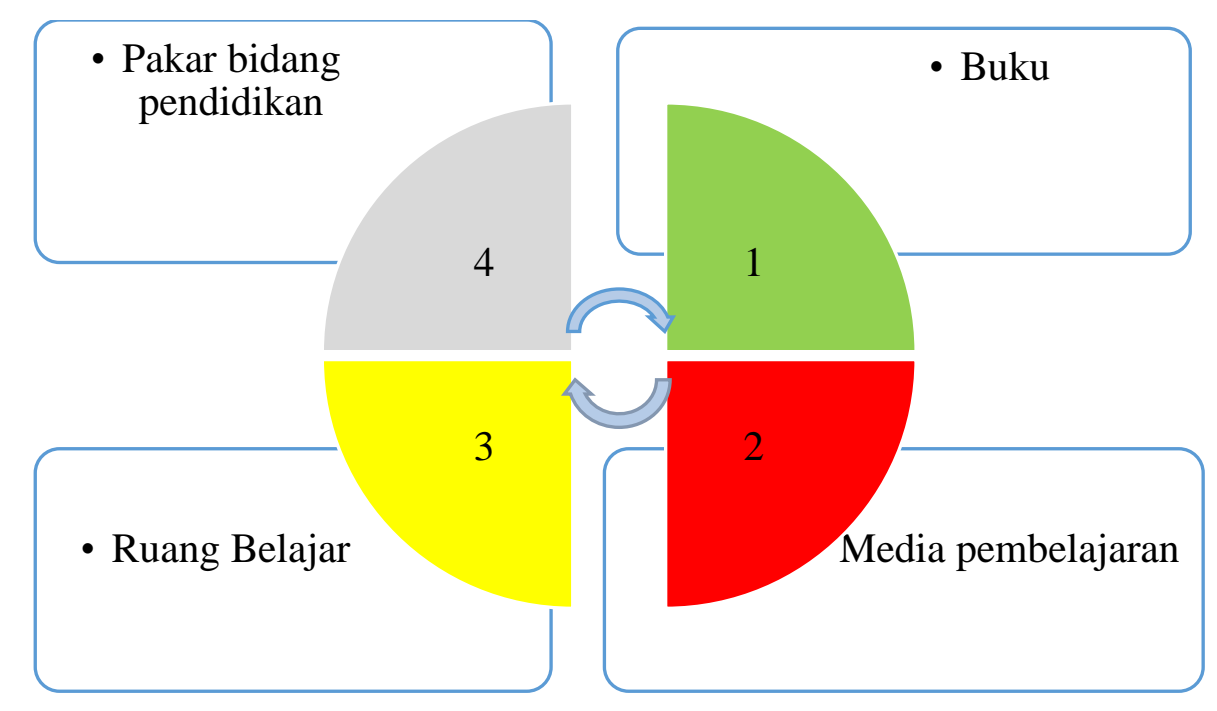

\section{Tindakan Solutif}

a. Tidak jarang pembelajaran Homeschooling akan mengakibatkan keterbatasan sosialisasi terhadap perserta didik oleh karena itu sebagai orang tua, keluarga atau guru pribadi membuat kelompok/ grup peserta didik homeschooling lainnya untuk berkumpul, belajar dan berinteraksi bersama.

b. Pembelajaran Homescooling juga membuat peserta didik menjadi kurang fokus karena dihadapkan dengan masalah dan suasana di rumah oleh karen itu orangtua atau keluarga sebisa mungkin tidak memperlihatkan dan melibatkan peserta didik terhadap masalah yang ada di rumah

c. Melengkapi fasilitas-fasilitas yang kurang memadai

d. Orang tua atau keluarga sebaiknya bersikap sewajarnya agar peserta didik tidak merasa dia berbeda dengan peserta didik sekolah pada umumnya

e. Di dalam Homeschooling tidak ada standar kurikulum namun bisa menerapkan kurikulum nasional, tetapi pada homeschooling lebih mengutamakan minat dan bakat peserta didik.

\section{Simpulan}

Homescooling menjadi tempat harapan orangtua dan keluarga untuk meningkatkan minat, potensi, bakat dan moral peserta didik serta mendapatkan suasana belajar yang menyenangkan. Adanya ketidakpuasan orangtua dan keluarga terhadap peserta didik di sekolah mengakibatkan 
orangtua memilih pembelajaran homeschooling agar peserta didik agar dapat meluangkan waktu dan fokus terhadap peserta didik.

Homescooling merupakan pendidikan alternatif yang didasarkan teori pendidikan kepribadian (humanistik). Pendidikan kepribadian merupakan konsep pendidikan yang lebih menekankan pada proses pengembangan kemampuan siswa. Materi ajaran dipilih yang sesuai dengan minat, kemampuan dan kebutuhan peserta didik.

\section{Referensi}

Fazra, A., Andin, F., Octaviani, H., Khasanah, U., Guru, P., Dasar, S., \& Cirebon, U. M. (2021). PENERAPAN SISTEM HOME SCHOOLING SEBAGAI INOVASI PEMBELAJARAN DI MASA PANDEMI COVID-19. 2019(Covid 19), 108-114.

Ghaisani, L. (2019). Pengaruh Homeschooling Terhadap Kemampuan Bersosialisasi Anak. 2015. https://doi.org/10.31227/osf.io/nc7pj

Fajri Kafarisa, R., \& Kristiawan, M. (2018). Kelas Komunitas Menunjang Terciptanya Karakter Komunikatif Peserta Didik Homeschooling Palembang. JMKSP (Jurnal Manajemen, Kepemimpinan, Dan Supervisi Pendidikan), 3(1), 68-76. https://doi.org/10.31851/jmksp.v3i1.1525

Karakter, P., \& Homeschooling, M. (2016). Pendidikan Karakter Melalui Homeschooling. Journal of Nonformal Education, 2(1). https://doi.org/10.15294/jne.v2i1.5316

Zulhafizh, Z. (2020). Membina Aktivitas Belajar Mahasiswa di Perguruan Tinggi Melalui Metode TIE (Translation, Interpretation, Extrapolation) pada Masa Pandemi Covid-19. Jurnal Kependidikan: Jurnal Hasil Penelitian Dan Kajian Kepustakaan Di Bidang Pendidikan, Pengajaran Dan Pembelajaran, 6(3), 502. https://doi.org/10.33394/jk.v6i3.2865

Muhtadi, A. (2012). Pendidikan dan pembelajaran di sekolah rumah (Homeschooling). Jakarta: Raja Grafindo Persada. 